Удк 550.3 (519.21)

Z. Vyzhva, Prof. E-mail: zoya_vyzhva@ukr.net,

V. Demidov, Assoc. Prof. E-mail, fondad@ukr.net Taras Shevchenko National University of Kyiv Institute of Geology, 90 Vasylkivska Str., Kyiv, 03022, Ukraine,

A. Vyzhva, researcher E-mail: motomustanger@ukr.net SE "Naykanafto-gaz", Kyiv, Ukraine, K. Fedorenko, postgraduate student E-mail: slims_mentol@mail.ru

Taras Shevchenko National University of Kyiv 90 Vasylkivska Str., Kyiv 03022, Ukraine

\title{
STATISTICAL SIMULATION OF 2D RANDOM FIELD WITH CAUCHY CORRELATION FUNCTION IN THE GEOPHYSICS PROBLEM OF ENVIRONMENT MONITORING
}

\begin{abstract}
(Рекомендовано членом редакційної колегії д-ром фіз.-мат. наук, проф. Б.П. Масловим)
Due to the increasing number of natural and technogenic disasters the development of geological environment monitoring system is actual using modern mathematical tools and information technology.

The local monitoring of potentially dangerous objects is an important part of the overall environment monitoring system.

Complex geophysical research was conducted on Rivne NPP area. Among these monitoring observations radioisotope study of soil density and humidity near the perimeter of buildings is of the greatest interest.

In this case a problem was occurred to supplement simulated data that were received at the control of chalky strata density changes at the research industrial area with use of radioisotope methods on a grid that included 29 wells.

This problem was solved in this work by statistical simulation method that provides the ability to display values (random field on a plane) in any point of the monitoring area. The chalk strata average density at the industrial area was simulated using the built model and the involvement of the Cauchy type correlation function.

This paper analyses the method and the model and procedure were developed with enough adequate data for Cauchy function.

The method and algorithm were developed and examples of karst-suffusion phenomena statistical simulation were given in the problem of density chalk strata monitoring at the Rivne NPP area. The statistical model of average density chalk strata distribution was built in the plane and statistical simulation algorithm was developed using Cauchy function on the basis of spectral decomposition. The research subject realizations were obtained with required detail and regularity at the observation grid based on the developed software. Statistical analysis of the numerical simulation results was done and tested its adequacy.
\end{abstract}

Keywords: Statistical simulation, function Cauchy, spectral decomposition, conditional maps.

Due to the increasing number of natural and technogenic disasters the development of geological environment monitoring system is actual using modern mathematical tools and information technology.

The local monitoring of potentially dangerous objects is an important part of the overall environment monitoring system.

Complex geophysical research was conducted on Rivne NPP area. Among these monitoring observations radioisotope study of soil density and humidity near the perimeter of buildings is of the greatest interest.

In this case a problem was occurred to supplement simulated data that were received at the control of chalky strata density changes at the research industrial area with use of radioisotope methods on a grid that included 29 wells.

This problem was solved in this work by statistical simulation method that provides the ability to display values (random field on a plane) in any point of the monitoring area. The chalk strata average density at the industrial area was simulated using the built model and the involvement of the Cauchy type correlation function.

In this paper the method is used and the model and procedure were developed with enough adequate data for Cauchy function.

The method and algorithm were developed and examples of karst-suffusion phenomena statistical simulation were given in the problem of density chalk strata monitoring at the Rivne NPP area. The statistical model of average density chalk strata distribution was built in the plane and statistical simulation algorithm was developed using Cauchy function on the basis of spectral decomposition. The research subject realizations were obtained with required detail and regularity at the observation grid based on the developed software. Statistical analysis of the numerical simulation results was done and its adequacy was tested.

Introduction. Due to the increasing number of natural and technogenic disasters the development of geological environment monitoring system is actual using modern mathematical tools and information technology.

The local monitoring of potentially dangerous objects is an important part of the overall environment monitoring system.

When monitoring such objects, a lot of problems were raised, for example, such as the lack of some data in the database, or insufficient quantity or necessity to supplement the database without conducting additional research.

Scientists Mantoglov A., Wilson John L. [8], Oliver, D. S. [9], Chiles J.P. and Delfiner P. [1], Prigarin, S. M. [10], Gneiting T. [3,4] and other researchers used statistical simulation techniques to solve geological problems over the past decade.

The Department of Geophysics at Institute of Geology and involved experts from Mechanics and Mathematics Faculty of Kyiv National Taras Shevchenko University in recent years developed theoretical and methodological application basics of statistical simulation in the development of geological environment monitoring.

Theoretical aspects of statistical simulation use to solve problems in the work of Geophysics were considered by Yadrenko M., Vyzhva Z. [2, 11]. Practical testing on real data of chalky strata density on the territory of the Rivne NPP was carried out for the fields on the plane by Vyzhva Z.O., Vyzhva S.A., Demidov V. K. [6], but with use of Bessel correlation function. In this paper the method is used and the model and procedure were developed with enough adequate data for Cauchy function.

Problem of karst-suffusion phenomena monitoring at Rivne NPP area. Complex geophysical research was conducted on Rivne NPP area. Among these monitoring observations radioisotope study of soil density and humidity near the perimeter of buildings is of the greatest interest. Soil density was determined by gamma-gamma well logging, soil humidity - by neutron-neutron logging.

In this case a problem occurred to supplement simulated data that were received at the control of chalky 
strata density changes at the research industrial area with use of radioisotope methods on a grid that included 29 wells. Schematic representation of the measurement results at the object that was investigated, and the well locations are shown on Fig. 1. These data are obviously not enough to represent the overall picture of the chalk strata, where due to the aggressive water action the karstsuffusion processes were significantly intensified.

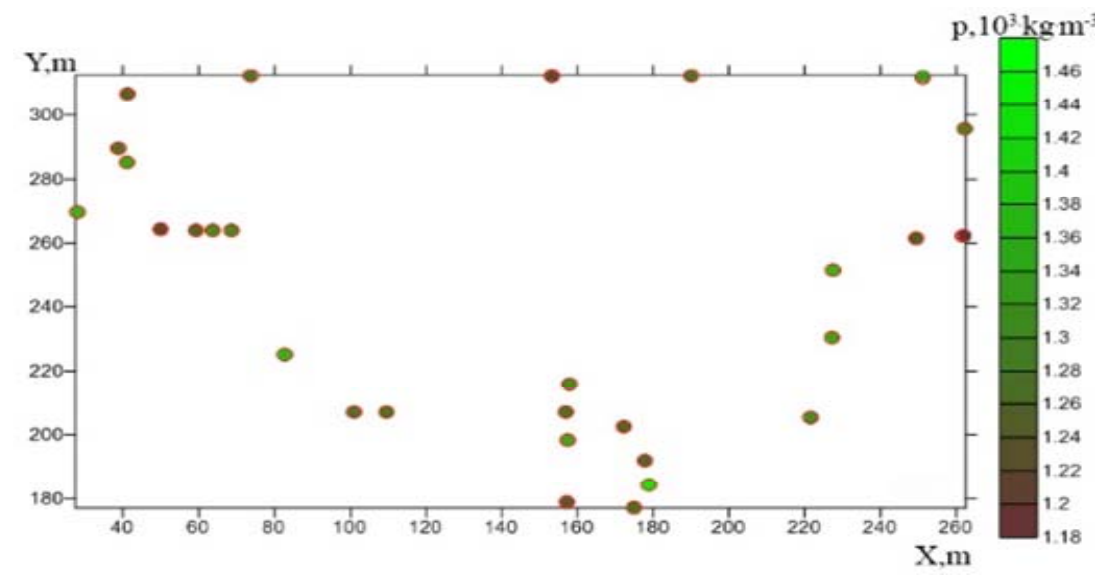

Fig.1. Observation points and chalk strata averaged density at industrial area of Rivne NPP

This problem was solved in work [5] by statistical simulation method that provides the ability to display values (random field on a plane) in any point of the monitoring area. The chalk strata average density at the industrial area was simulated using the built model and the involvement of the Bessel type correlation function.

This work continues development of methods for statistical simulation, involving Cauchy correlation function that is well-known in Geostatistics [1,3].

Before using developed mathematical tools to radioisotope research real data of soil density at the observation area their preliminary preparation and statistical analysis was carried out.

At the data preparation stage the measurement errors were excluded (for the operator, the equipment, observation conditions, etc.). With this purpose the following things were made:

- Firstly, the top layer was rejected (about 10 meters), as it consists of mixed bulk soil;

- Secondly, well data were aggregated for the different years to the average, which was calculated for three years in anchor wells (the reference loam layer was selected that lies above the chalk layer). For loam layer the average value for three years was calculated and then the corresponding corrections were put into data with a "+" or "-" sign. Such processing was done by STATISTICA software.

This operation was done for data array of density chalk strata in 1984-2002 years' for 29 wells at Rivne NPP industrial area and depth is $28 \mathrm{~m}$ below the surface.

The method of solving the problem. Data of density chalky strata was divided into deterministic and random components. Deterministic function can be selected by the method of approaching the minimum curve (separation of the trend). The difference between the map of input density values and the trend is in most cases a homogeneous isotropic random field. With the assumption that the input data is a random field $\eta(\bar{x})$, then we express them through a random component $\xi \overline{(x)}$ (so-called "noise" random field) and trend $f(\bar{x})$ as a deterministic function as follows:

$$
\eta(\bar{x})=f(\bar{x})+\xi(\bar{x})
$$

Thus, the problem was reduced to simulation of random component $\xi \overline{(x)}$, which in most cases is a homogeneous and isotropic.

Consider the same approach as in $[2,6,7]$. We use the method of statistical simulation of random fields, which are homogenous and isotropic, based on their spectral decomposition. By means of the obtained values of realizations, this technique allows to find the perfect image of these isotropic fields in the whole observation interval.

It is necessary to make the statistical analysis to build the model and procedure of statistical data simulation at observation area. If the verified data have distribution density with approximately Gaussian type, then procedure can be used, which is developed in $[2,6,7]$, to generate on the computer realizations of the simulated data by means of standard normal random variable sequences.

At first the distribution is determined. The preliminary statistical analysis of data shows that the distribution histogram of chalky strata density at the Rivne industrial area (29 boreholes) approximately has Gaussian distribution (Fig. 2).

The use of authors' techniques of statistical simulation implies preliminary statistical data processing to determine its statistical characteristics: the mathematical expectation and the correlation function. If the hypothesis of Gaussian distribution of the investigated field is confirmed, then the mathematical expectation and the correlation function completely define this field and give us the opportunity to build the adequate statistical model, which is based on spectral decomposition of random functions. The principles of constructing the models and procedures are described below. 


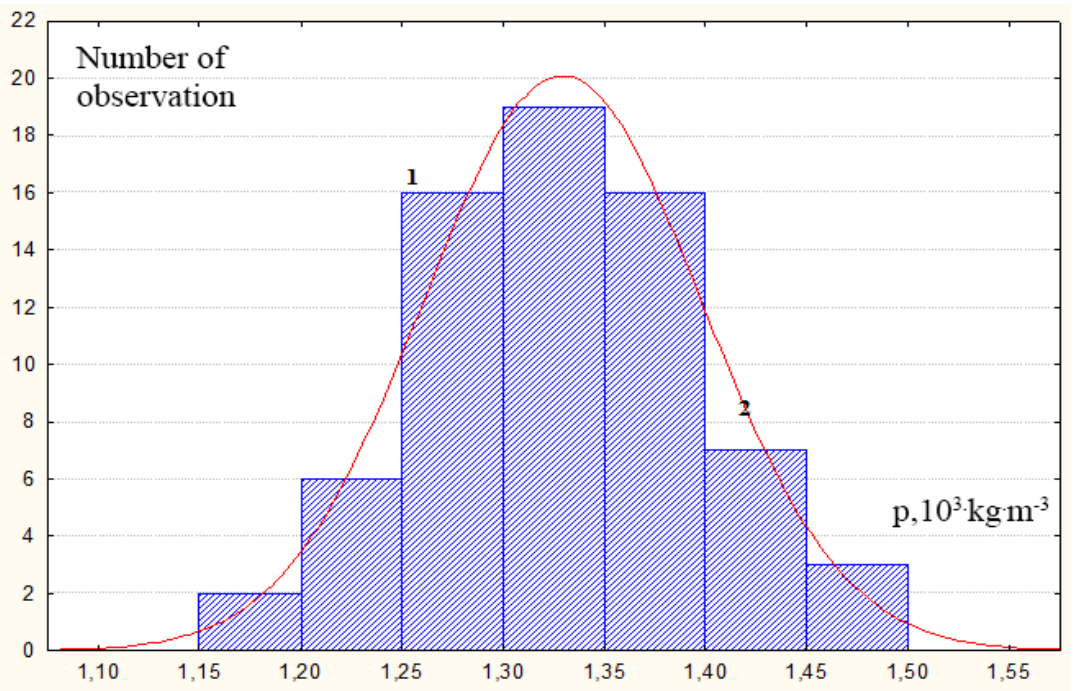

Fig.2. Histogram of the chalky strata density (averaged data for all years of observation):

1 - the number of observations in a separate range of density; 2 - theoretical Gaussian curve

Then the statistical model was chosen for the data correlation function for distribution of chalky strata density in the flat observation area. This function is defined by comparing the mean square approximation of the empirical and theoretical variograms. As result the input data was most adequately described by means of two types of correlation functions: the Bessel function (1) at the value of parameter $a=5$ and the Cauchy function (2) at the value of parameter $a=1$ :

$$
B(\rho)=J_{0}(a \rho), \quad a=5 ;
$$

$$
B(\rho)=\frac{a^{4}}{\left(a^{2}+\rho^{2}\right)^{2}}, \quad a=1 .
$$

The variogram of input data of chalky strata density, corresponding to the Cauchy correlation function (2), was built by using the $R$ software and geoR package The plot was presented at Figure 3, according to the Cauchy correlation function (2) variogram of the random component of investigation data.

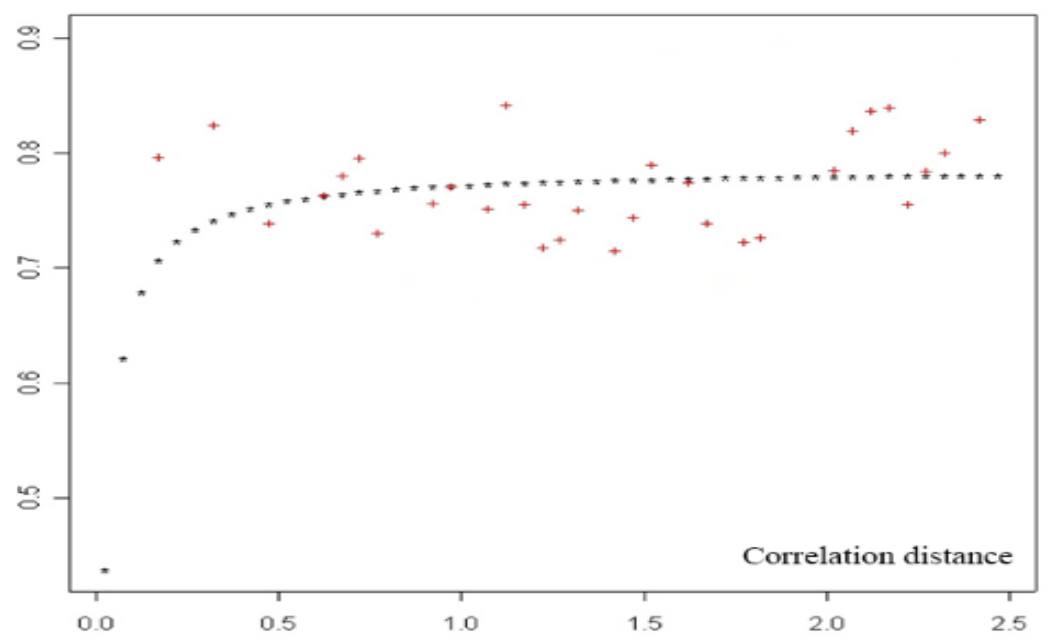

Fig.3. Variogram of input data of the chalky strata,

that corresponding to the Cauchy correlation function $B(\rho)=\frac{a^{4}}{\left(a^{2}+\rho^{2}\right)^{2}}, \quad a=1$

Note that the generalized Cauchy model is:

$$
B(\rho)=\left(1+\frac{\rho^{2}}{a^{2}}\right)^{-v}, \quad v>0, a>0 .
$$

The generalized Cauchy model (3) was studied by A. M. Yaglom [12]. T. Gneiting [3] who considered the Cauchy function at the values of the parameter $v=1 / 2,3 / 2,5 / 2$, $7 / 2$.
Graphic representations of the Cauchy function at different values of parameters $v$ and at $a=1$ are presented in Fig. 4. 


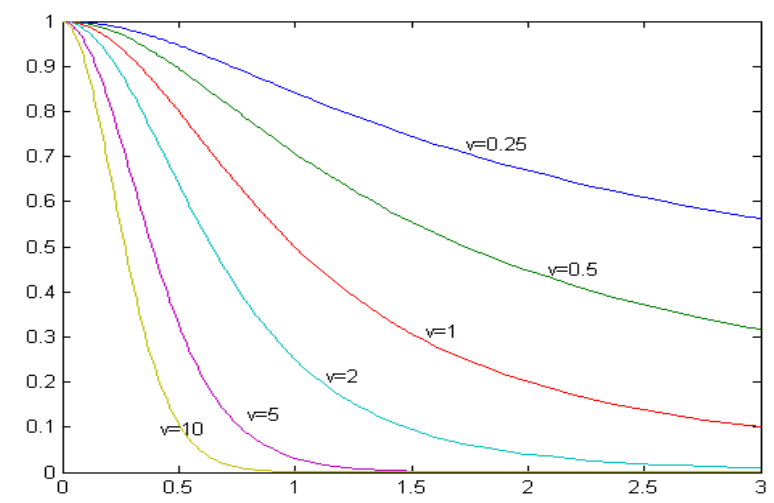

Fig.4. The Cauchy function at parameter values $a=1$ and $v=0.25,0.5,1,2,5$ and 10

Let us find the spectral density, which corresponds to the Cauchy correlation function (2), by using the formula
6.565 (4) and 8.486 (16) [5]. Formula 6.565 (4) is mentioned below as:

$$
\int_{0}^{\infty} \frac{J_{v}(b x) x^{\nu+1}}{\left(a^{2}+x^{2}\right)^{\mu+1}} d x=\frac{a^{\nu-\mu} b^{\mu}}{2^{\mu} \Gamma(\mu+1)} K_{v-\mu}(a b), a>0, \quad b>0, \operatorname{Re} v<\operatorname{Re}(2 \mu+3 / 2) .
$$

and the ratio $8.486(16)$ is written as follows:

$$
K_{-v}(z)=K_{v}(z)
$$

Then such spectral density is calculated by conducting the following formula:

$$
f(\lambda)=\lambda \int_{0}^{\infty} x J_{0}(\lambda x) B(x) d x=\lambda \int_{0}^{\infty} x J_{0}(\lambda x) \frac{a^{4}}{\left(a^{2}+x^{2}\right)^{2}} d x,
$$

Thus the spectral density, which is corresponding to the Cauchy correlation function (2), is:

$$
f(\lambda)=\frac{1}{2} a^{3} \lambda^{2} K_{1}(a \lambda)
$$

where $K_{1}(x)$ is a modified Hankel function of order 1.

The spectral coefficients, which, according to such correlation function, are determined by calculating the integral:

$$
\begin{gathered}
b_{k}(r)=2 \int_{0}^{\infty} J_{k}^{2}(r u) d \Phi(u)=a^{3} \int_{0}^{\infty} u^{2} J_{k}^{2}(r u) K_{1}(a u) d u= \\
2 \frac{r^{2 k}(1+k)}{a^{2 k}} F_{4}\left(1+k, 2+k ; k+1, k+1 ;-\frac{r^{2}}{a^{2}},-\frac{r^{2}}{a^{2}}\right) .
\end{gathered}
$$

Thus the spectral coefficients, that correspond to the Cauchy correlation function (2), are written as follow:

$$
b_{k}(r)=\frac{2^{1+2 k} r^{2 k} a}{\left(a+\sqrt{a^{2}+4 r^{2}}\right)^{2 k}} \frac{\left(a^{2}+2 r^{2}+a k \sqrt{a^{2}+4 r^{2}}\right)}{\left(a^{2}+4 r^{2}\right)^{3 / 2}} \text {. }
$$

These spectral coefficients are calculated by Mathematica software.

The model of 2D random field with Cauchy correlation function and the numerical simulation procedure. The realizations of $2 \mathrm{D}$ random field with Cauchy correlation function (3) at the values of parameters $a=1$ are generated. The statistical simulation was performed by the technique of spectral decomposition and finding of spectral coefficients.

From the spectral theory [11] it follows that the model of random fields on a plane with such correlation function is a sum of:

$$
\begin{aligned}
\xi_{\mathrm{N}}(\mathrm{r}, \phi) & =\sum_{\mathrm{k}=0}^{\mathrm{N}} \sqrt{v_{\mathrm{k}} \mathrm{b}_{\mathrm{k}}(\mathrm{r})}\left[\zeta_{\mathrm{k}}(\mathrm{r}) \operatorname{cosk} \phi+\eta_{\mathrm{k}}(\mathrm{r}) \operatorname{sink} \phi\right], \\
\text { where: } v_{\mathrm{k}} & =\left\{\begin{array}{l}
1, \mathrm{k}=0 ; \\
2, \mathrm{k}>0,
\end{array}\right.
\end{aligned}
$$

- $r$ and $\phi\left(r \in R_{+}, \phi \in[0,2 \pi]\right)$ are polar coordinates of the point $x$ on the plane (includes observation area), and the distance $\rho$ between the points $x_{1}=\left(r_{1}, \varphi_{1}\right)$ and $\mathrm{x}_{2}=\left(\mathrm{r}_{2}, \varphi_{2}\right)$ equals $\rho=\sqrt{\mathrm{r}_{1}^{2}+\mathrm{r}_{2}^{2}-2 \mathrm{r}_{1} \mathrm{r}_{2} \cos \left(\phi_{1}-\phi_{2}\right)}$,

- $\mathrm{N}$ is an integer number (the number of the summands in the model), the value of $\mathrm{N}$ is determined by the prescribed small number $\varepsilon$ (approximation accuracy) by the inequality from paper [2], which is the estimate of the mean square approximation of random field $\xi(r, \varphi)$ by partial sums $\xi_{\mathrm{N}}(\mathrm{r}, \varphi)$;

- $\mathrm{b}_{\mathrm{k}}(\mathrm{r}),(\mathrm{k}=0,1,2, \ldots \mathrm{N})$ are the spectral coefficients in form of (5), which correspond to the Cauchy correlation function (2);

- $\mathrm{J}_{\mathrm{k}}(\mathrm{x})$ is the Bessel function of the first kind of order $\mathrm{k}$, the parameter a has the same value as the correlation function $\left(a \approx 3,5^{*} 10^{-5}\right)$.

The procedure of numerical simulation realizations of the data field random component, by means of the abovementioned model (6), was conducted by using the Spectr 2.1 software, which is described in [6].

The value of number $\mathrm{N}$ for the constructed model is determined by the inequality, which is the estimate of the mean square approximation of random field $\xi(\mathrm{r}, \varphi)$ by partial sums $\xi_{\mathrm{N}}(\mathrm{r}, \varphi)$. This number $\mathrm{N}$ corresponds to the prescribed small number $\varepsilon$ (approximation accuracy). The mentioned inequality was obtained in work [1] and in form of:

$$
\mathrm{M}\left[\xi(r, \phi)-\xi_{N}(r, \phi)\right]^{2} \leq \frac{1}{\pi N}\left(\frac{1}{2} r \mu_{1}+r^{2} \mu_{2}\right),
$$

where $\mu_{\mathrm{k}}=\int_{0}^{\infty} \lambda^{\mathrm{k}} \mathrm{d} \Phi(\lambda)$.

Define dependence number $N$ on $r$ and $\varepsilon$ in the case of Cauchy correlation function (3). It is necessary to calculate the values of $\mu_{k}, \kappa=1,2$ for the inequality (7), by using the density of distribution (4) and the following formula $6.561(16)[5]$ :

$$
\int_{0}^{\infty} x^{\mu} K_{v}(a x) d x=2^{\mu-1} a^{-\mu-1} \Gamma\left(\frac{1+\mu+v}{2}\right) \Gamma\left(\frac{1+\mu-v}{2}\right) .
$$


Then the calculated values hold:

$$
\mu_{1}=\frac{a^{3}}{2} \int_{0}^{\infty} \lambda^{3} K_{1}(a \lambda) d \lambda=\frac{3 \pi}{4 a}, \mu_{2}=\frac{a^{3}}{2} \int_{0}^{\infty} \lambda^{4} K_{1}(a \lambda) d \lambda=\frac{8}{a^{2}} .
$$

Consequently the estimate of the mean square approximation of the random field $\xi(r, \varphi)$ with Cauchy correlation function (3) by the partial sums $\xi_{N}(r, \varphi)$ has the following representation:

$$
N(r, \varepsilon) \geq \frac{1}{\pi \varepsilon}\left(\frac{1}{2} r \mu_{1}+r^{2} \mu_{2}\right)=\frac{1}{\pi \varepsilon}\left(\frac{3 r \pi}{8 a}+\frac{8 r^{2}}{a^{2}}\right)
$$

The statistical simulation procedure of Gaussian homogeneous isotropic random field $\xi(\mathrm{r}, \varphi)$ on the plane was built by means of the model (6) and the estimate (8). This random field is determined by its statistical characteristics: the mathematical expectation and the Cauchy correlation function $\mathrm{B}(\rho)(3)$ at the value of parameter $a=1$.

\section{Procedure:}

1) The positive integer number $N$ is determined corresponding to the prescribed accuracy $\varepsilon$ and by using inequality (8), where $r$ is a radius of the point on the plane in which the realization of the random field $\xi(r, \varphi)$ is generated. The integer number $\mathrm{N}$ equals 59 by using the prescribed accuracy $\varepsilon=5 \times 10^{2}$ and values of parameters $v=2, \quad a=1$

2) We calculated the spectral coefficients at the value of parameter $\mathrm{a}=1$ :

$$
b_{k}(r)=\frac{2^{1+2 k} r^{2 k}}{\left(1+\sqrt{1+4 r^{2}}\right)^{2 k}} \frac{\left(1+2 r^{2}+k \sqrt{1+4 r^{2}}\right)}{\left(1+4 r^{2}\right)^{3 / 2}} .
$$

3) We generate values of the standard normal random variables $\left\{\zeta_{k}, k=0,1,2, \ldots, 59\right\}$ and $\left\{\eta_{k}, k=0,1,2, \ldots, 59\right\}$.
4) We evaluate the expression (6) by substituting in it values which were found in the previous steps $\varphi_{i}=i \times \frac{2 \pi}{10}, \quad i=0, \ldots, 9, r_{i}=0.1 \times i, \quad i=1, \ldots, 10$.

5) The statistical estimate of the correlation function is obtained by the realizations of the random $\xi(r, \varphi)$. This estimate compares with a given correlation function at $a=1$ and provides the statistical analysis the adequacy of realization.

Note that the procedure can be applied to random fields with another type of distribution. Then the random variables $\left\{\zeta_{k}(r), \quad k=0,1,2, \ldots, N\right\}$ and $\left\{\eta_{k}(r), \quad k=0,1,2, \ldots, N\right\}$ should be distributed by corresponding law.

The original Spectr software, based on the results of the statistical data processing and the mentioned procedure for the simulation values of such data realization in the two-dimensional case, was developed in Delphi, where selected Cauchy correlation function (2) was used.

The results, which were obtained by the simulating procedure, are displayed in Figure 5. Figure 5 (a) presents an example of constructed map of chalky strata density according to data boreholes observations (average data over the years to 29 boreholes at $28 \mathrm{~m}$ ) by Surfer software. Using available data, the accurancy of this construction cannot provide a reliable characteristic of the chalky strata status, because the number of measurement results is not sufficient.

Fig. 5 (b) presents the contours of equal values of chalky strata density based on simulated data including values of the anchor boreholes by means of calculating the spectral coefficients. Additionally, the output data (160 simulated values in intervals between the observation points of this level) can have more reliable approximation that enables more informed decisions about the status of chalky strata and determines places for testing and additional research.

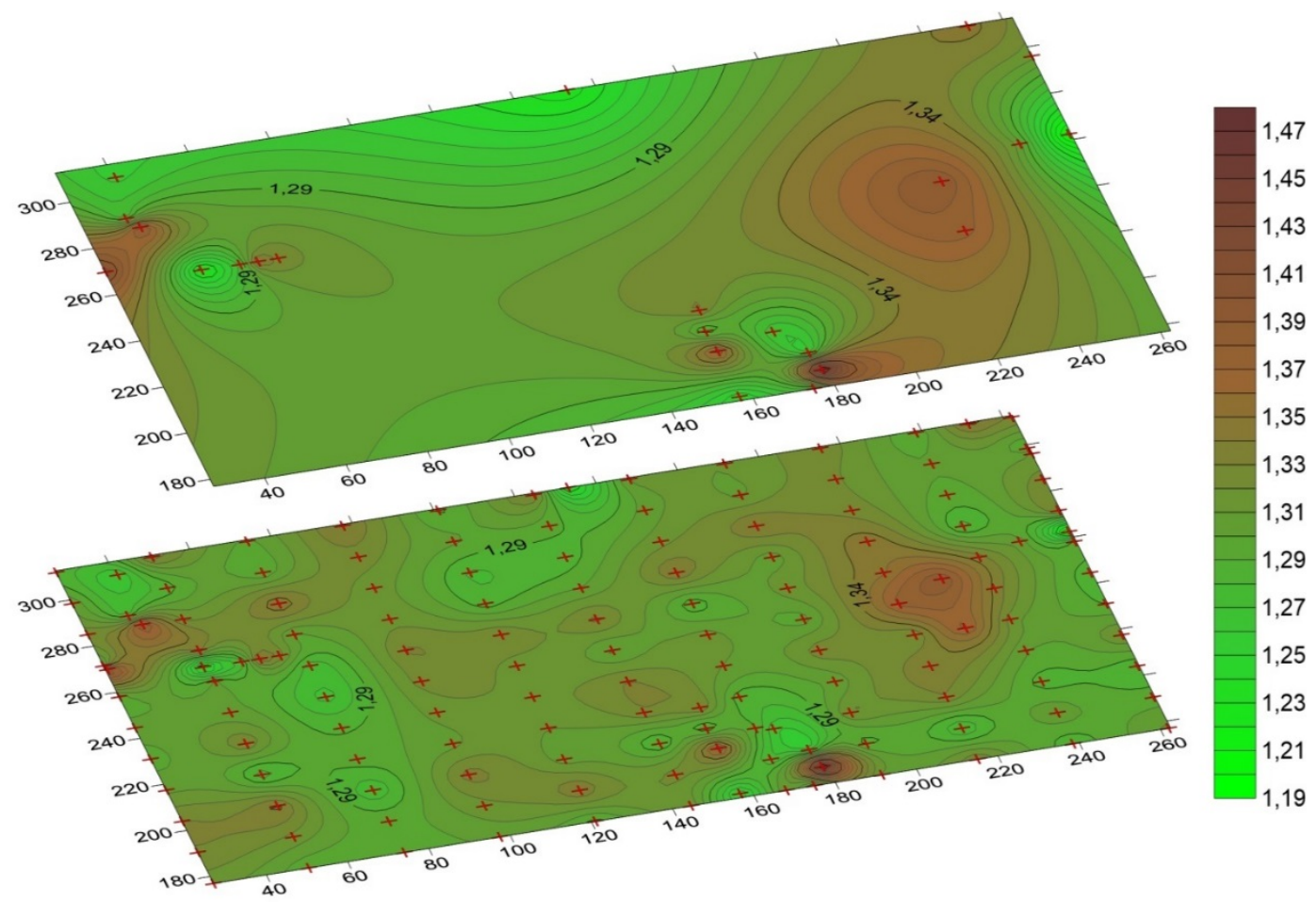

Fig.5. The distribution of chalky strata density on the industrial area of Rivne nuclear power plant at a depth of $28 \mathrm{~m}$. from the surface, according to the average data of 29 observational boreholes over 1984-2004 years.

(a) for the simulated data based on the values in secure boreholes by spectral coefficients (b) 
The following Fig. 6 presents the plot of the variogram of the separated random data component of chalky strata density according to Cauchy correlation functions
(Fig. 6, (a)) and plot of the variogram of the simulated random data component according to Cauchy correlation functions (2) (Fig. 6, (b)).
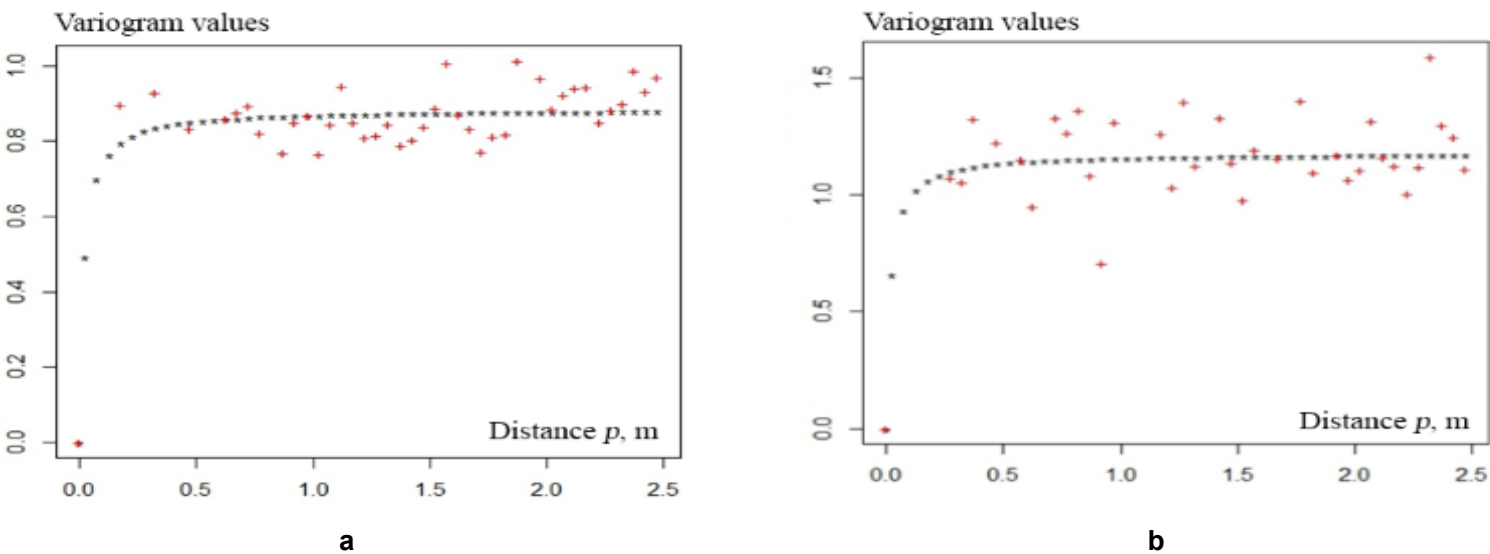

Fig. 6. The variogram (a) of separated random data component of the chalky strata density,

$$
\text { corresponding to Cauchy correlation function } B(\rho)=\frac{a^{4}}{\left(a^{2}+\rho^{2}\right)^{2}}, \quad a=1 \text {; }
$$

(b) of simulated random data component, corresponding to Cauchy correlation function $B(\rho)=\frac{a^{4}}{\left(a^{2}+\rho^{2}\right)^{2}}, a=1$

The results present that the chosen model of the data is rather adequate. The developed Spectr2_1 software works with sufficient accuracy.

Conclusions. The theory, techniques and procedure of statistical simulation of 2D random fields can significantly increase the effectiveness of monitoring observations on the territory of potentially dangerous objects. This makes it possible to simulate the values in the area between anchor observation grid and beyond, and to adequately describe real geological processes.

The method of statistical simulation of random fields with Cauchy correlation functions allows complementing the data with a given accuracy. It can also be used to detect abnormal areas.

Список використаних джерел

1. Chiles J.P. Geostatistics: Modeling Spatial Uncertainty / J.P. Chiles, P. Delfiner. - NewYork, Toronto, JohnWiley\&Sons, Inc.,1999. - 695 p.

2. Grikh Z.(Vyzhva Z.) About Approximation and Statistical Simulation of Izotropic Fields / Z. Grikh, M. Yadrenko, O. Yadrenko // Random Operators and Stohastic Equations. - 1993. - Vol. 1, № 1. - P. 37-45

3. Gneiting T. Symmetric Positive Definite Functions with Applications in Spatial Statistics. Von der Universitat Bayeuth zur Erlangung des Grades eines Doktors der Naturwissenschaften/ T. Gneiting / (Dr. rer. nat.) genehmigte Abhandlung, 1997. - $107 \mathrm{p}$.

4. Gneiting T. Matérn cross-covariance functions for multivariate random fields./ T. Gneiting, W. Kleiber, M. Schlather // Journal of the American Statistical Association. - 2010. - Vol. 105. - P. 1167-1177.

5. Gradshteyn I.S. Tables of Integrals, Series and Products / I.S. Gradshteyn, I.M. Ryzhik // Moscow: Nauka. - 1971. - 1108 p.

6. Vyzhva Z.O. The statistical simulation of karst suffosion processes on territiry potentially dangerous objects./ Z.O. Vyzhva, S.A. Vyzhva, V.K. Demidov // Geoinformatica. - 2004. - № 2. - P. 78-85.

7. Vyzhva Z. O.The Statistical Simulation of Random Processes and Fields / Z.O.Vyzhva - Kyiv: Obrii, 2011. - 388 p.

8. Mantoglov A. Simulation of random fields with turning bands method/ A. Mantoglov, John L. Wilson // "MIT Ralph M.Parsons Lab. Hydrol. and Water Syst. Rept". - 1981. - № 264. - 199 p.

9. Oliver D.S. Gaussian Cosimulation: Modelling of the CrossCovariance, / D.S. Oliver / Mathematical Geology. - 2003. - Vol. 35. P. 681-698.
10. Prigarin S.M. Numerical Modeling of Random Processes and Fields / S.M. Prigarin / Editorin Chief G.A. Mikhailov. - Novosibirsk: Inst. of Comp. Math. and Math. Geoph. Publ., 2005. - P. 259.

11. Yadrenko M. Y. Spectral theory of random fields / M.Y. Yadrenko / Optimization Software Inc., Publications Division, NewYork, 1983. - P. 259.

12. Yaglom A.M. Correlation Theory of Stationary and Related Random Functions./ A.M. Yaglom / Basic Results. Springer, New York. 1987. - Vol.1, 2.

\section{References}

1. Chiles J.P., Delfiner P. (1999). Geostatistics: Modeling Spatial Uncertainty. NewYork, Toronto. JohnWiley\&Sons, Inc., 695 p.

2. Grikh Z., Yadrenko M., Yadrenko O. (1993). About Approximation and Statistical Simulation of Izotropic Fields. Random Operators and Stohastic Equations, 1, 1, 37-45.

3. Gneiting T. (1997). Symmetric Positive Definite Functions with Applications in Spatial Statistics. Von der Universitat Bayeuth zur Erlangung des Grades eines Doktors der Naturwissenschaften (Dr. rer. nat.) genehmigte Abhandlung, $107 \mathrm{p}$.

4. Gneiting T., Kleiber W., Schlather M. (2010). Matérn crosscovariance functions for multivariate random fields. Journal of the American Statistical Association, 105, 1167-1177.

5. Gradshteyn I.S., Ryzhik I.M. (1971). Tables of Integrals, Series and Products. Moscow: Nauka, 1108 p. [in Russian]

6. Vyzhva Z.O., Vyzhva S.A., Demidov V.K. (2004). The statistical simulation of karst suffosion processes on territiry potentially dangerous objects. Geoinformatica, 2, 78-85.

7. Vyzhva Z. O.(2011). The Statistical Simulation of Random Processes and Fields. Kyiv: Obrii, $388 \mathrm{p}$.

8. Mantoglov A., Wilson John L. (1981). Simulation of random fields with turning bands method. 'MIT Ralph M.Parsons Lab. Hydrol. and Water Syst. Rept", 264, 199 p

9. Oliver D.S. (2003). Gaussian Cosimulation: Modelling of the CrossCovariance. Mathematical Geology, 35, 681-698.

10. Prigarin S.M. (2005). Numerical Modeling of Random Processes and Fields. Editorin Chief G.A. Mikhailov. Novosibirsk: Inst. of Comp. Math. and Math. Geoph. Publ., 259 p.

11. Yadrenko M. Y. (1983). Spectral theory of random fields. Optimization Software Inc.. Publications Division, NewYork, $259 \mathrm{p}$.

12. Yaglom A.M. (1987). Correlation Theory of Stationary and Related Random Functions. Basic Results. Springer. New York, 1, 2.

Надійшла до редколегії 23.01.17 
3. Вижва, проф.

E-mail: zoya_vyzhva@ukr.net,

В. Демидов, доц.

E-mail: fondad@ukr.net

Київський національний університет імені Тараса Шевченка

вул. Васильківська 90, м. Київ, 03022, Україна,

А. Вижва, наук. співроб.

E-mail: motomustanger@ukr.net

ДП "Науканафто-газ",

К. Федоренко, асп.

E-mail: slims_mentol@mail.ru

Київський національний університет імені Тараса Шевченка

вул. Васильківська 90, м. Київ, 03022, Україна

\section{СТАТИСТИЧНЕ МОДЕЛЮВАННЯ ДВОВИМІРНОГО ВИПАДКОВОГО ПОЛЯ 3 КОРЕЛЯЦІЙНОЮ ФУНКЦІЄЮ ТИПУ КОШІ \\ В ГЕОФІЗИЧНІЙ ЗАДАЧІ МОНІТОРИНГУ ДОВКІЛЛЯ}

У зө'язку з ростом кількості природно-техногених катастроф актуальною є розробка систем моніторингу за станом геологічного середовища з використанням сучасного математичного апарату та інформаційних технологій. В загальній системі моніторингу довкілля важливою складовою є локальний моніторинг територій розташування потенційно небезпечних об'єктів.

На території розміщення Рівненської АЕС проводився комплекс геофізичних досліджень. Серед цих моніторингових спостережень найбільший інтерес представляють радіоізотопні дослідження густини та вологості ґрунтів по периметру збудованих споруд. При цьому виниклає проблема доповнення даних шляхом моделювання, яке проводиться при контролі зміни густини крейдяної товщі на території досліджуваного проммайданчика з використанням радіоізотопних методів по сітці, що включала 29 свердловин. Цю задачу в роботі було вирішено методом статистичного моделювання, який надає можливість відображати явище (випадкове поле на площині) у будь-якій точці області спостереження. При цьому моделювалися усереднені значення густини крейдяної товщі на території проммайданчика із використанням побудованої моделі та залученням кореляційної функції Коші.

В цій роботі представлено розроблений метод, алгоритм та приклад статистичного моделювання карстово-суфозійних явищ у задачі моніторингу густини крейдяної товщі на території Рівненської АЄС. За спектральним розкладом побудовано статистичну модель розподілу усередненої густини товщі на площині та розроблено алгоритм статистичного моделювання з використанням функції Коші. На базі розробленого програмного забезпечення отримано модельні параметри густини крейдяної товщі на сітці спостережень необхідної детальності та регулярності. Проведено статистичний аналіз результатів чисельного моделювання та їх перевірку на адекватність.

Ключові слова: статистичне моделювання, функція Коші, спектральний розклад, кондиційність карт.

3. Выжва, проф.

E-mail: zoya_vyzhva@ukr.net,

В. Демидов, доц.

E-mail: fondad@ukr.net

Киевский национальный университет имени Тараса Шевченка

ул. Васильковская, 90, г. Киев, 03022, Украина,

А. Выжва, науч. сотрудник

e-mail: motomustanger@ukr.net

ДП "Науканафто-газ",

К. Федоренко, асп.

E-mail: slims_mentol@mail.ru

Киевский национальный университет имени Тараса Шевченка

ул. Васильковская, 90, г. Киев, 03022, Украина

\section{СТАТИСТИЧЕСКОЕ МОДЕЛИРОВАНИЕ ДВУМЕРНОГО СЛУЧАЙНОГО ПОЛЯ \\ С КОРРЕЛЯЦИОННОЙ ФУНКЦИЕЙ ТИПА КОШИ \\ В ГЕОФИЗИЧЕСКОЙ ЗАДАЧЕ МОНИТОРИНГА ОКРУЖАЮЩЕЙ СРЕДЫ}

Рост количества природно-техногенных катастроф требует разработки систем мониторинга состояния геологической среды с использованием современного математического аппарата и информационных технологий. В общей системе мониторинга окружающей среды важной составляющей является локальный мониторинг территорий размещения потенциально опасных обьектов.

На территории Ровенской АЄС проведен комплекс геофизических исследований. Среди этих мониторинговых исследований наибольший интерес представляют радиоизотопные исследования плотности и влажности грунтов по периметру построенных сооружений. При этом возникет проблема дополнения данных посредством моделирования, которое проведится при контроле изменения плотности меловой толщи на территории исследуемой промплощадки с использованием радиоизотопных методов по сетке, которая включала 29 скважин. Данная задача была решена в работе методом статистического моделирования, который даёт возможность отображать явление (случайное поле на плоскости) в любой точке области наблюдения. При этом моделировались усреднённые значения плотности меловой толщи на территории промплощадки с использованием модели, построенной с использованием корреляционной функции Коши.

В этой работе разработаны метод и алгоритм, а также приведен пример статистического моделирования карстовосуффозионных явлений для задачи мониторинга плотности меловой толщи на территории Ровенской АЭС. По спектральному разложению построена статистическая модель распределения плотности меловой толщи на плоскости и разработан алгоритм статистического моделирования с использованием функции Коши. На базе разработанного программного обеспечения получены параметры плотности меловой толщи по сетке наблюдений необходимой детальности и регулярности. Проведен статистический анализ результатов численного моделирования и их проверка на адекватность.

Ключевые слова: статистическое моделирование, функция Коши, спектральное разложение, кондиционность карт. 